\title{
Developing Critical Thinking Skills In The Intermediate Accounting Class: Using Simulations With Rubrics
}

Karen T. Cascini, (E-mail: cascinik@scredheart.edu), Sacred Heart University Anne J. Rich, (E-mail: Anne.Rich@quinnipiac.edu), Quinnipiac University

\begin{abstract}
A challenge of paramount importance facing college professors today is the development of students' capacity for critical thinking skills. While this has long been an area of focused activity for educators, since the early 1980s in particular, it has become clear that critical thinking skills are essential to the ability of our students to compete globally. As teachers and professors at all levels have begun to focus greater attention on ways to develop critical thinking skills, we see the same trend reflected within the accounting profession. Research by Kealy (2005), Bonk (1998), Wolcott (1997), Kimmel (1995), and Doney (1993) demonstrates this interest among accounting faculty for students at both introductory and advanced levels. This paper defines critical thinking and explores tools that currently exist to develop the critical thinking skills of accounting students. Two particular tools, simulations and rubrics, are examined closely. This paper reports the results of a research study designed to assess the usefulness of rubrics, when combined with a simulation exercise, in an intermediate accounting class and its direct relationship to critical thinking skills related to performing analyses. While the use of the rubric did not appear to make a difference in the ability of students to perform complex analyses and draw conclusions in simulation exercise, the results of this research study highlight the need for accounting educators to continue to explore ways to develop strategies for improving students' critical thinking skills.
\end{abstract}

\section{DEFINING CRITICAL THINKING}

criven and Paul (2005) describe critical thinking as having two components: A set of information and belief generating and processing skills as well as the habit based on intellectual commitment of using those skills to guide retention of behavior. The authors believe that critical thinking is more than just acquiring information or rote memorization. They define critical thinking as a "mode of thinking about any subject, content or problem in which the "thinker improves the quality of his or her thinking by skillfully taking charge of the structures inherent in thinking and imposing intellectual standards upon them". Experts in this area agree that critical thinkers are able to ask key questions, gather information, assess relevant information and think open-mindedly.

According to Peter Facione (2004) critical thinking includes:

1. Interpretation - to comprehend and express the meaning or significance of a wide variety of experience, situations, data, events, judgments, convention, beliefs, rules, procedures or criteria.

2. Analysis-to identify the intended and actual inferential relationships among statements, questions, concepts, descriptions or other forms of representation intended to express belief, judgment, experiences, reasons, information or opinions.

3. Evaluation-to assess the credibility of statements or other representations which are accounts or descriptions of a person's perceptions, experience, situation, judgment, belief, or opinion; and to assess the logical strength of the actual or intended inferential relationships among statements, descriptions, questions or other forms of representation (comparing the strengths and weaknesses of alternative interpretations). 
4. Inference- to identify and secure elements needed to draw reasonable conclusions; to form conjectures and hypotheses; to consider relevant information and deduce the consequences flowing from data, statements, principles, evidence, judgments, beliefs, opinions, concepts, descriptions, questions or other forms of representations when faced with a problem developing a set of options to address it.

5. Explanation- being able to state the results of one's reasoning; to justify the reasoning in terms of evidential, conceptual, methodological, criteriological, and contextual considerations upon which one's results are based. Explain what one thinks and how one arrived at the judgment.

6. Self-regulation- meta-cognition - raises thinking to another level - looks back at all the dimensions of critical thinking and double-checks itself. One can monitor and correct an inference one has drawn. Involves selfexamination and self-correction.

Experts also agree that critical thinkers are self-directed, self-disciplined, self-monitored and self-corrective thinkers. Baril et al (1998) provides us with a review of the many studies relating critical thinking to accounting during the 1987 - 1999 period. As with other professions, it is clear that the accounting profession uses the term critical thinking to refer to a broad set of competencies and skills including both cognitive and non-cognitive attributes, attitudes and behaviors. Reinstein (1997) and Riordan (1992) are among many academicians and practitioners to emphasize that if students are to be successful in the accounting profession, critical thinking skills must be developed in the classroom. The importance of such skills is reflected in the CPA examination. This exam tests the candidates' critical thinking skills by incorporating questions requiring them to perform analyses and reach conclusions. While the subject of critical thinking has been studied for the last two decades, there is still need for further examination. Burnett (2003) provides the result of a recent survey of practitioners who rated critical thinking as one of four necessary professional skills for accountants. The author states, "now, more than ever, it is imperative that changes be made for accounting education to survive."

How can accounting faculty help students improve their critical thinking skills? Faculty must create a learning environment that starts with a strong foundation of basic skills and knowledge and then moves on to more complex challenging situations. According to the National Education Association, "The rational powers of any person are developed gradually and continuously as and when he used them successfully. There is no evidence that they can be developed in any other way. They do not emerge quickly or without effort" (Riordan, 1992). Thus, we can understand why a variety of methods have been introduced in the college curriculum to develop critical thinking skills for our students.

Two tools that have gained popularity in the accounting classroom are cases and simulations. For many accounting topics, cases are now available from textbook publishers and business organizations. For example, the accounting firm of Deloitte provides their Trueblood cases, and the American Accounting Association regularly publishes cases in Issues in Accounting Education. Also, the Financial Accounting Standards Board has "Cases in Recognition and Measurement" as a resource for faculty. In addition, the American Institute of Certified Public Accountants regularly publish their professor-practitioner cases. Friedian (1995) showed the use of cases along with an interactive learning environment emphasizing that critical thinking skills has a significant positive effect on students' perceptions. In addition, courses that use this teaching method are more likely to produce students who possess qualities consistent with those needed in the accounting profession.

Business simulations have also been developed for classroom use. For the Principles of Accounting course, Springer and Borthick (2004) describe their simulation's goal of shifting students away from well-structured end- of chapter problems to a situation with a high degree of uncertainty. Their research shows the importance of using simulations to develop higher order thinking skills.

Intermediate accounting texts have responded to the need to expose students to more critical-thinking, challenging situations. For example, one popular intermediate accounting text, Keiso, Weygandt, and Warfield's eleventh edition Intermediate Accounting, includes simulations to help students develop an understanding of the numbers. 
However, in assigning simulation, students often express their concern that they do not know where to begin an assignment that requires analyses and conclusions. Cases and simulations sometimes have stated learning objectives to help, but often provide little guidance on where to start and how to complete the assignment. Rubrics have been developed to assist students in developing a more extensive solution to an unstructured problem. A rubric is a tool that identifies criteria that serve as guidelines for evaluators in rating student performance on the assessment activity and conveys the evidence that will be used to evaluate the competency. Ammons and Mills (2005) demonstrated the effectiveness of providing rubrics in an integrative business course. They found that rubrics could convey to students what constitutes quality performance. Wiggens offers some guidelines on distinguishing students who seem to have a deep understanding from those who do not. If shared with students prior to grading, rubrics can then serve to clarify expectations and can enhance communication in the classroom about linkages between teaching, learning, and assessment.

\section{RESEARCH DESIGN}

This is a study of the effectiveness of rubrics to improve critical thinking by accounting majors in the intermediate accounting class. Faculty employed at two private universities in the northeast developed the assignments and assessments. Both institutions offer a business major and an accounting major within their respective schools of business. Overall, the universities have similar class sizes and teaching orientations.

During the Fall 2005 semester, two faculty teaching the first intermediate financial accounting course required students to complete two in-class homework assignments having to do with the preparation of the cash flow statement and a graded assignment.

Four intermediate accounting classes participated in this study, two classes in each university. Past research by the authors indicated that the students were very homogeneous. Table 1 shows the average SAT scores for students at each university. Most of the students were full-time students who fell within the traditional age group. However, there were some part-time students who were over the age of 24. Most of the students were accounting majors.

Table 1

SAT Scores By University

\begin{tabular}{|c|c|c|}
\hline & University \#1 & University \#2 \\
\hline SAT scores: Verbal & 490 & 547 \\
\hline SAT scores: Math & 552 & 591 \\
\hline
\end{tabular}

There were a total of 72 students in the study. Two classes were selected to receive the rubric, while two classes were not. All students were assigned the same reading and were assigned the same in-class exercises and homework assignments related to the topic of cash flow. Table 2 shows the number of students in each of the four classes:

Table 2

Number Of Students Participating In The Study

\begin{tabular}{|c|c|c|c|}
\hline Class & University \#1 & University \#2 & Total students \\
\hline Received rubric & 20 & 13 & 33 \\
\hline Did not receive rubric & 17 & 22 & 39 \\
\hline Total students & 37 & 35 & 72 \\
\hline
\end{tabular}

The first homework assignment involved the preparation of a cash flow statement. The second assignment built on the first and required some analyses and conclusions. The reading included a discussion of several ratios that 
students might employ in drawing conclusions about the liquidity and financial flexibility of a particular company. Students were also asked to complete an end-of-chapter simulation. A third assignment was a graded simulation exercise designed to further increase the students' analytical skills. This third assignment required students, once again, to prepare a cash flow statement from the data presented. However, it also required the student to calculate specific ratios and draw conclusions about the liquidity and financial flexibility of the company. All students completed the homework assignment. The solutions to all three assignments were given to the students. A rubric was developed for each assignment and these are included in the appendix. The rubrics were given to students in two of the four sections to guide them in answering the assignments. Students were asked to self-grade their solutions based on the rubric's guidelines.

Students were informed that there would be an examination covering the subject of the cash flow statement among other topics. They were informed that the test would include analyses and conclusions concerning the liquidity and financial flexibility of the company. The examination questions included three parts as follows: (1) Preparation of the cash flow statement (2) Analyses and conclusions on the liquidity of the company and (3) Analyses and conclusions on the solvency of the company. All students were then given the same exam question. The exam question was in the same format as the graded homework and contained the same requirements. The examination question is found in the appendix.

Our research hypotheses relating to the effectiveness of the rubric were as follows:

1. Students who previously were given a rubric will perform better on technical aspects of the preparation of the cash flow statement than those who were not given a rubric

2. Students who previously were given a rubric will perform better on the analysis and conclusions relating liquidity questions than those who were not previously given a rubric.

3. Students who previously were given a rubric will perform better on the analysis and conclusions relating to financial flexibility questions than those who were not previously given a rubric.

In order to grade the students' responses, a grading grid was established. A total of 100 points was assigned to the preparation of the cash flow statement. Table 3 reveals the seven-point scale that was developed to assess the critical thinking skills of the student in responding to the analysis and conclusion requirement. Both instructors reviewed the scoring together to assure consistency of interpretation of the grid.

Table 3

Grading Of Liquidity And Flexibility Analysis Questions

\begin{tabular}{|l|c|}
\hline Level of Skill & Score \\
\hline Did not answer or gave wrong answer & 0 \\
\hline Defined concept (liquidity or flexibility) & 1 \\
\hline Provided some ratio or analysis to support explanation but not most relevant ratio & 2 \\
\hline Drew correct conclusions based on some analysis but not most relevant ratio & 3 \\
\hline Provided the most appropriate or relevant ratio & 4 \\
\hline Provided some calculation of the relevant ratio - but made some error in analysis or conclusion & 5 \\
\hline Drew correct conclusion based on correct calculation of the most relevant ratio & 6 \\
\hline
\end{tabular}

The results: The overall test results are shown in Table 4. 
Table 4

Overall Test Results

\begin{tabular}{|c|c|c|c|c|}
\hline University & Number of students & $\begin{array}{c}\text { Average grade on } \\
\text { technical question }\end{array}$ & $\begin{array}{c}\text { Average grade on } \\
\text { liquidity analysis }\end{array}$ & $\begin{array}{c}\text { Average grade on } \\
\text { flexibility analysis }\end{array}$ \\
\hline 1 & 37 & 80 & 3.38 & 1.62 \\
\hline 2 & 35 & 88 & 4.66 & 4.23 \\
\hline
\end{tabular}

Table 5

Test Results By Treatment

\begin{tabular}{|c|c|c|c|c|}
\hline Treatment & Number of students & $\begin{array}{c}\text { Average grade on } \\
\text { technical question }\end{array}$ & $\begin{array}{c}\text { Average grade on } \\
\text { liquidity analysis }\end{array}$ & $\begin{array}{c}\text { Average grade on } \\
\text { flexibility analysis }\end{array}$ \\
\hline Did not receive rubric & 33 & 82.6 & 3.97 & 2.73 \\
\hline Received rubric & 39 & 84.6 & 4.03 & 3.03 \\
\hline
\end{tabular}

Students at university 2 performed somewhat better on the technical preparation of the cash flow statement (the average was $88 \%$ compared to an average of $80 \%$ ). In addition, it appears that students at university \#2 performed somewhat better on the liquidity and significantly better on the flexibility analysis questions. However, these differences cannot be attributed to the rubric. The data was further analyzed to see if the means were representative of the data. Tables 6, 7 and 8 show the distribution of the grades on the liquidity and financial flexibility analysis questions. From Table 7 we can determine that a third of the students (24 out of 72) were not able to receive a score greater than 3. However, while the treatment did not seem to impact the score, it does appear that students from university \#2 did better than students from university \#1. Similar results are seen in Tables 9, 10 and 11 in reviewing the scores for the financial flexibility analysis. Fifty-five percent of all students answering could not score above 3 . However, students from university 2 performed better than students from university 1 .

Table 6

Overall Student Scores On The Liquidity Analysis

\begin{tabular}{|c|c|c|c|c|c|}
\hline \multicolumn{2}{|c|}{} & Frequency & Percent & Valid Percent & Cumulative Percent \\
\hline Valid & .00 & 15 & 20.8 & 20.8 & 20.8 \\
\hline & 1.00 & 2 & 2.8 & 2.8 & 23.6 \\
\hline & 2.00 & 4 & 5.6 & 5.6 & 29.2 \\
\hline & 3.00 & 3 & 4.2 & 2.2 & 33.3 \\
\hline & 5.00 & 19 & 26.4 & 40.3 & 59.7 \\
\hline & 6.00 & 29 & 40.3 & 100.0 & 100.0 \\
\hline & Total & 72 & 100.0 & & \\
\hline
\end{tabular}

Table 7

Count

Student Liquidity Scores By University

\begin{tabular}{|c|c|c|c|c|c|c|c|c|}
\hline & & \multicolumn{6}{|c|}{ Liquidity Scores } & \multirow[t]{2}{*}{ Total } \\
\hline & & .00 & 1.00 & 2.00 & 3.00 & 5.00 & 6.00 & \\
\hline \multirow[t]{2}{*}{ University } & 1 & 12 & 1 & 2 & 1 & 9 & 12 & 37 \\
\hline & 2 & 3 & 1 & 2 & 2 & 10 & 17 & 35 \\
\hline \multicolumn{2}{|c|}{ Total } & 15 & 2 & 4 & 3 & 19 & 29 & 72 \\
\hline
\end{tabular}


Table 8

Count

Student Liquidity Scores By Treatment

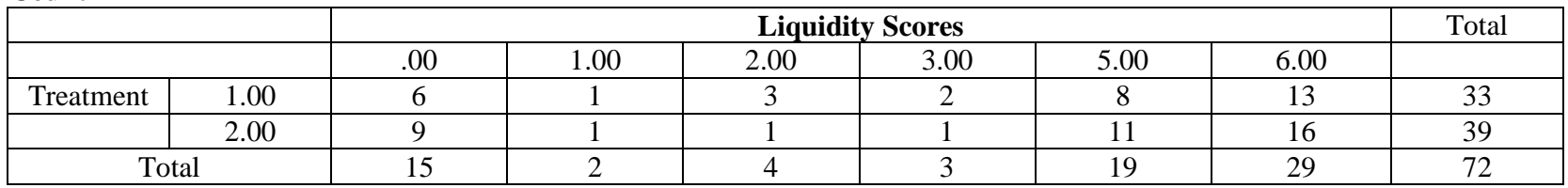

Table 9

Overall Student Scores On The Financial Flexibility Analysis

\begin{tabular}{|c|c|c|c|c|c|}
\hline \multicolumn{2}{|c|}{} & Frequency & Percent & Valid Percent & Cumulative Percent \\
\hline Valid & .00 & 27 & 37.5 & 37.5 & 37.5 \\
\cline { 2 - 6 } & 1.00 & 2 & 2.8 & 2.8 & 40.3 \\
\cline { 2 - 6 } & 2.00 & 2 & 2.8 & 2.8 & 43.1 \\
\cline { 2 - 6 } & 3.00 & 9 & 12.5 & 12.5 & 55.6 \\
\cline { 2 - 6 } & 5.00 & 17 & 23.6 & 23.6 & 79.2 \\
\cline { 2 - 6 } & 6.00 & 15 & 20.8 & 20.8 & 100.0 \\
\cline { 2 - 6 } & Total & 72 & 100.0 & 100.0 & \\
\hline
\end{tabular}

Table 10

Student Financial Flexibility Scores By University

Count

\begin{tabular}{|c|c|c|c|c|c|c|c|c|}
\hline \multicolumn{2}{|c|}{} & \multicolumn{9}{c|}{ Flexibility Scores } & \multirow{2}{*}{ Total } \\
\cline { 3 - 10 } \multicolumn{2}{c|}{} & .00 & 1.00 & 2.00 & 3.00 & 5.00 & 6.00 & 3 \\
\hline \multirow{2}{*}{ University } & 1 & 22 & 2 & 2 & 2 & 6 & 37 & 35 \\
\cline { 2 - 10 } & 2 & 5 & 0 & 0 & 7 & 11 & 12 & 15 \\
\hline \multicolumn{2}{|c|}{ Total } & 27 & 2 & 2 & 9 & 17 & 72 \\
\hline
\end{tabular}

Table 11

Student Financial Flexibility Scores By Treatment

Count

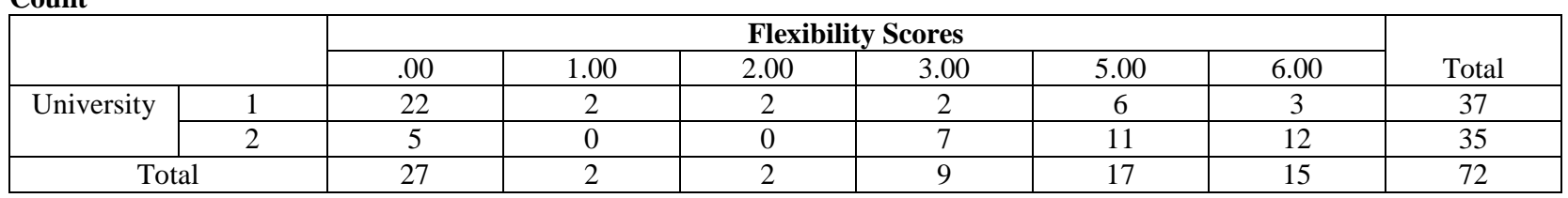

\section{DISCUSSION AND CONCLUSION}

None of the hypotheses could be supported by this research. Rubrics did not assist students in intermediate accounting to perform better on the technical preparation or the analysis questions. Some possible reasons for this result are as follows:

1. The rubrics provided were not relevant to help students develop the skills required for this task. Rubrics most be designed to provide guidance for students to develop their analytical abilities.

2. Perhaps the rubric was relevant but not used in a way that would be effective. The rubric was only applied to this topic. Students may have been unfamiliar with the use of a rubric. In addition, students were asked to use the rubric without the involvement of the professor.

3. Intermediate accounting students already have a basic knowledge of the concepts. Rubrics may be more helpful to students who have little fundamental understanding of a topic. 
While there was no difference between those who received the rubric and those who did not, there was a clear difference in the performance by students from university \#2 compared to those of university \#1. We discount the possibility that the difference is due to teaching ability of the instructors. This is primarily because results from prior research studies involving these two faculty did not show any differences due to instructor. Thus we propose some other possible reasons for the difference in performance.

1. There may have been differences in the students' abilities and motivation. While past research suggested that students from both universities were similar in abilities, the students in University \#1 in the Fall 2005 class demonstrated a lower skill level than those studied in the past.

2. The instructors may have used class time differently. Students tend to focus on elements stressed by their professors. It may be that the professor in University \#2 stressed some points more than the professor from University \#1.

The most important findings of this research are that overall the students in both schools did very poorly. Despite the building blocks associated with teaching the statement of cash flows and despite the use of simulations, students performed very poorly on the critical thinking questions. While most students were able to prepare the cash flow statement from a technical perspective, they were unsuccessful at the higher-level tasks of performing analyses and communicating conclusions. We conclude that it is not sufficient for accounting educators to expose students to simulations or to provide rubrics. Clearly, an isolated experience does not develop critical thinking skills. Similarly, providing rubrics with little instructor feedback is ineffective. Instructors need to (1) expose students to continuous critical-thinking activities and (2) provide continuous feedback to students. Lynch and Wolcott (2001) suggest that faculty introduce students to "steps for better thinking." They state "students are more likely to develop skills if they understand the goals and receive explicit feedback about their performance." This clearly presents challenges to accounting faculty who are more familiar with the traditional approach of focusing on the technical aspects of assignments. Students need to be exposed to open-ended questions that often do not have one correct answer. Creating an environment that fosters critical-thinking is time-consuming and challenging.

Future research should explore the impact of students' critical thinking skills on their performance in the area of accounting. Researchers should use the available standardized instruments to measure critical thinking skills in this regard. In addition, future research should consider the impact of how class time is utilized. Professors influence students by highlighting concepts in class. The content as well as length of time used in the classroom to review technical and critical thinking issues are likely to have a significant influence on students' performance.

This research study has shown that the use of a simulation exercise as a means of enhancing critical thinking skills is a useful beginning. It will not however, accomplish the objective of adequately preparing all students to analyze and report results. The use of rubrics, which have been shown to be effective in introductory classes, does not seem to have the same result in intermediate accounting. Perhaps self-grading rubrics are not as helpful as those graded by the instructor. More instructor feedback will require more of the instructor's time. As the accounting profession demands higher level thinking, it is essential that accounting faculty help develop students' critical thinking skills. The challenge is how to accomplish this objective. 


\section{APPENDIX}

Rubric \#1: Preparation Of Cash-Flow Statement - Classification And Measurement

\begin{tabular}{|l|l|l|l|l|}
\hline \multicolumn{1}{|c|}{$\begin{array}{c}\text { Performance } \\
\text { Measurement }\end{array}$} & \multicolumn{1}{|c|}{ "A" response } & "B" response & "F" response \\
\hline $\begin{array}{l}\text { Classification of cash } \\
\text { flows }\end{array}$ & $\begin{array}{l}\text { Able to recognize and } \\
\text { classify operating, } \\
\text { investing and } \\
\text { financing activities }\end{array}$ & $\begin{array}{l}\text { Able to recognize and } \\
\text { classify operating, but } \\
\text { does not recognize one } \\
\text { of the financing and } \\
\text { investing activities }\end{array}$ & $\begin{array}{l}\text { Able to properly } \\
\text { recognize and classify } \\
\text { operating activities } \\
\text { but does not recognize } \\
\text { two or more of the } \\
\text { financing and } \\
\text { investing activities }\end{array}$ & $\begin{array}{l}\text { Unable to properly } \\
\text { classify operating, } \\
\text { financing or investing } \\
\text { activities }\end{array}$ \\
\hline $\begin{array}{l}\text { Measurement of cash } \\
\text { flows }\end{array}$ & $\begin{array}{l}\text { Able to properly } \\
\text { calculate the amounts } \\
\text { associated with } \\
\text { operating, investing } \\
\text { and financing activities }\end{array}$ & $\begin{array}{l}\text { Able to properly } \\
\text { calculate operating } \\
\text { activities, but does not } \\
\text { calculate one of the } \\
\text { financing and } \\
\text { investing activities }\end{array}$ & $\begin{array}{l}\text { Able to properly } \\
\text { calculate operating } \\
\text { activities, but does not } \\
\text { calculate two or more } \\
\text { of the financing and } \\
\text { investing activities }\end{array}$ & $\begin{array}{l}\text { Unable to calculate } \\
\text { operating, financing or } \\
\text { investing activities }\end{array}$ \\
\hline
\end{tabular}

Rubrics \#2: Cash Flow Statement - Classification, Measurement And The Concept Of Free Cash Flow

\begin{tabular}{|l|l|l|l|l|}
\hline \multicolumn{1}{|c|}{$\begin{array}{c}\text { Performance } \\
\text { Measurement }\end{array}$} & \multicolumn{1}{|c|}{ "A" response } & \multicolumn{1}{c|}{ "B" response response } & "F" response \\
\hline $\begin{array}{l}\text { Classification of cash } \\
\text { flows }\end{array}$ & $\begin{array}{l}\text { Able to recognize and } \\
\text { classify operating, } \\
\text { investing and } \\
\text { financing activities }\end{array}$ & $\begin{array}{l}\text { Able to recognize and } \\
\text { classify operating, but } \\
\text { does not recognize one } \\
\text { of the financing and } \\
\text { investing activities }\end{array}$ & $\begin{array}{l}\text { Able to properly } \\
\text { recognize and classify } \\
\text { operating activities } \\
\text { but does not recognize } \\
\text { two or more of the } \\
\text { financing and } \\
\text { investing activities }\end{array}$ & $\begin{array}{l}\text { Unable to properly } \\
\text { classify operating, } \\
\text { financing or investing } \\
\text { activities }\end{array}$ \\
\hline $\begin{array}{l}\text { Measurement of cash } \\
\text { flows }\end{array}$ & $\begin{array}{l}\text { Able to properly } \\
\text { calculate the amounts } \\
\text { associated with } \\
\text { operating, investing } \\
\text { and financing activities }\end{array}$ & $\begin{array}{l}\text { Able to calculate } \\
\text { operating activities, } \\
\text { but does not calculate } \\
\text { one of the financing } \\
\text { and investing activities }\end{array}$ & $\begin{array}{l}\text { Able to calculate } \\
\text { operating activities, } \\
\text { but does not calculate } \\
\text { two or more of the } \\
\text { financing and } \\
\text { investing activities }\end{array}$ & $\begin{array}{l}\text { Unable to calculate } \\
\text { operating, financing or } \\
\text { investing activities }\end{array}$ \\
\hline $\begin{array}{l}\text { Conceptual } \\
\text { understanding of free } \\
\text { cash flows }\end{array}$ & $\begin{array}{l}\text { Able to provide } \\
\text { accurate definition of } \\
\text { free cash flows and } \\
\text { makes reference to } \\
\text { concept of financial } \\
\text { flexibility }\end{array}$ & $\begin{array}{l}\text { Describes free cash } \\
\text { flows accurately but } \\
\text { makes no reference to } \\
\text { the concept of } \\
\text { financial flexibility }\end{array}$ & $\begin{array}{l}\text { Describes free cash } \\
\text { flows imprecisely and } \\
\text { makes no reference to } \\
\text { the concept of } \\
\text { financial flexibility }\end{array}$ & $\begin{array}{l}\text { Provides no definition } \\
\text { of free cash flows or } \\
\text { any reference to the } \\
\text { concept of financial } \\
\text { flexibilitiy }\end{array}$ \\
\hline
\end{tabular}




\section{PROFESSIONAL SIMULATION: ACCOUNTING - STATEMENT OF CASH FLOWS WITH ANALYSIS}

\section{Rubric \#3: Prepare The Statement Of Cash Flows Including Calculations Of The free Cash Flow And The Current Cash Debt Coverage Ratios, Current And Acid-Test Ratios and The Assessment Of Liquidity And Financial Flexibility}

\begin{tabular}{|l|l|l|l|l|}
\hline \multicolumn{1}{|c|}{$\begin{array}{c}\text { Performance } \\
\text { Measurement }\end{array}$} & \multicolumn{1}{|c|}{ "A" response } & \multicolumn{1}{|c|}{ "B" response } & "F" response & response \\
\hline $\begin{array}{l}\text { Classification of cash } \\
\text { flows }\end{array}$ & $\begin{array}{l}\text { Able to recognize and } \\
\text { classify operating, } \\
\text { investing and } \\
\text { financing activities }\end{array}$ & $\begin{array}{l}\text { Able to recognize and } \\
\text { classify operating, but } \\
\text { does not recognize one } \\
\text { of the financing and } \\
\text { investing activities }\end{array}$ & $\begin{array}{l}\text { Able to properly } \\
\text { recognize and classify } \\
\text { operating activities } \\
\text { but does not recognize } \\
\text { two or more of the } \\
\text { financing and } \\
\text { investing activities }\end{array}$ & $\begin{array}{l}\text { Unable to properly } \\
\text { classify operating, } \\
\text { financing or investing } \\
\text { activities }\end{array}$ \\
\hline $\begin{array}{l}\text { Measurement of cash } \\
\text { flows }\end{array}$ & $\begin{array}{l}\text { Able to properly } \\
\text { calculate the amounts } \\
\text { associated with } \\
\text { operating, investing } \\
\text { and financing activities }\end{array}$ & $\begin{array}{l}\text { Able to calculate } \\
\text { operating activities, } \\
\text { but does not calculate } \\
\text { one of the financing } \\
\text { and investing activities }\end{array}$ & $\begin{array}{l}\text { Able to calculate } \\
\text { operating activities, } \\
\text { but does not calculate } \\
\text { two or more of the } \\
\text { financing and } \\
\text { investing activities }\end{array}$ & $\begin{array}{l}\text { Unable to calculate } \\
\text { operating, financing or } \\
\text { investing activities }\end{array}$ \\
\hline $\begin{array}{l}\text { Conceptual } \\
\text { understanding of free } \\
\text { cash flows }\end{array}$ & $\begin{array}{l}\text { Able to provide } \\
\text { accurate definition of } \\
\text { free cash flows and } \\
\text { makes reference to } \\
\text { concept of financial } \\
\text { flexibility }\end{array}$ & $\begin{array}{l}\text { Describes free cash } \\
\text { flows accurately but } \\
\text { makes no reference to } \\
\text { the concept of } \\
\text { financial flexibility }\end{array}$ & $\begin{array}{l}\text { Describes free cash } \\
\text { flows imprecisely and } \\
\text { makes no reference to } \\
\text { the concept of } \\
\text { financial flexibility }\end{array}$ & $\begin{array}{l}\text { Provides no definition } \\
\text { of free cash flows or } \\
\text { any reference to the } \\
\text { concept of financial } \\
\text { flexibiity }\end{array}$ \\
\hline
\end{tabular}

\begin{tabular}{|c|c|c|c|c|}
\hline $\begin{array}{l}\text { Performance } \\
\text { Measurement }\end{array}$ & "A" response & "B" response & "C" response & "F" response \\
\hline $\begin{array}{l}\text { Conceptual } \\
\text { understanding of } \\
\text { current debt coverage } \\
\text { ratio }\end{array}$ & $\begin{array}{l}\text { Able to provide } \\
\text { accurate definition of } \\
\text { current debt coverage } \\
\text { ratio and makes } \\
\text { reference to concepts } \\
\text { of financial liquidity } \\
\text { and flexibility }\end{array}$ & $\begin{array}{l}\text { Describes the current } \\
\text { debt coverage ratio, } \\
\text { make reference to its } \\
\text { use in financial } \\
\text { analysis but makes no } \\
\text { reference to the } \\
\text { concepts of financial } \\
\text { liquidity or financial } \\
\text { flexibility }\end{array}$ & $\begin{array}{l}\text { Describes the current } \\
\text { debt coverage ratio but } \\
\text { makes no reference to } \\
\text { the it use in financial } \\
\text { analysis }\end{array}$ & $\begin{array}{l}\text { Provides no definition } \\
\text { of the current debt } \\
\text { coverage ratio nor any } \\
\text { reference to its use in } \\
\text { financial analysis }\end{array}$ \\
\hline $\begin{array}{l}\text { Measurement of } \\
\text { current debt coverage } \\
\text { ratio }\end{array}$ & $\begin{array}{l}\text { Able to properly } \\
\text { calculate the amounts } \\
\text { and presents the } \\
\text { correct result }\end{array}$ & $\begin{array}{l}\text { Able to calculate the } \\
\text { numerator and } \\
\text { denominator correctly } \\
\text { but did not present the } \\
\text { result correctly; }\end{array}$ & $\begin{array}{l}\text { Able to calculate only } \\
\text { the numerator or } \\
\text { denominator correctly } \\
\text { but not both }\end{array}$ & $\begin{array}{l}\text { Not able to perform the } \\
\text { calculation }\end{array}$ \\
\hline $\begin{array}{l}\text { Conceptual } \\
\text { understanding of } \\
\text { current ratio }\end{array}$ & $\begin{array}{l}\text { Able to provide } \\
\text { accurate definition of } \\
\text { current ratio and } \\
\text { makes reference to } \\
\text { concept of financial } \\
\text { liquidity }\end{array}$ & $\begin{array}{l}\text { Describes the current } \\
\text { ratio, make reference } \\
\text { to its use in financial } \\
\text { analysis but makes no } \\
\text { reference to the } \\
\text { concept of financial } \\
\text { liquidity }\end{array}$ & $\begin{array}{l}\text { Describes the current } \\
\text { ratio but makes no } \\
\text { reference to the it use } \\
\text { in financial analysis }\end{array}$ & $\begin{array}{l}\text { Provides no definition } \\
\text { of the current ratio nor } \\
\text { any reference to the } \\
\text { concept of financial } \\
\text { liquidity }\end{array}$ \\
\hline $\begin{array}{l}\text { Measurement of } \\
\text { current ratio }\end{array}$ & $\begin{array}{l}\text { Able to properly } \\
\text { calculate the amounts } \\
\text { and presents the } \\
\text { correct result }\end{array}$ & $\begin{array}{l}\text { Able to calculate the } \\
\text { numerator and } \\
\text { denominator correctly } \\
\text { but did not present the } \\
\text { result correctly; }\end{array}$ & $\begin{array}{l}\text { Able to calculate only } \\
\text { the numerator or } \\
\text { denominator correctly } \\
\text { but not both }\end{array}$ & $\begin{array}{l}\text { Not able to perform the } \\
\text { calculation }\end{array}$ \\
\hline
\end{tabular}




\begin{tabular}{|c|c|c|c|c|}
\hline $\begin{array}{l}\text { Conceptual } \\
\text { Understanding of } \\
\text { acid-test (quick) ratio }\end{array}$ & $\begin{array}{l}\text { Able to provide an } \\
\text { accurate definition of } \\
\text { acid-test ratio and } \\
\text { makes reference to } \\
\text { concept of financial } \\
\text { liquidity }\end{array}$ & $\begin{array}{l}\text { Describes the acid-test } \\
\text { ratio, make reference } \\
\text { to its use in financial } \\
\text { analysis but makes no } \\
\text { reference to the } \\
\text { concept of financial } \\
\text { liquidity }\end{array}$ & $\begin{array}{l}\text { Describes the acid-test } \\
\text { ratio but makes no } \\
\text { reference to the it use } \\
\text { in financial analysis }\end{array}$ & $\begin{array}{l}\text { Provides no definition } \\
\text { of the acid-test ratio } \\
\text { nor any reference to } \\
\text { the concept of } \\
\text { financial liquidity }\end{array}$ \\
\hline $\begin{array}{l}\text { Measurement of acid- } \\
\text { test (quick) ratio }\end{array}$ & $\begin{array}{l}\text { Able to properly } \\
\text { calculate the amounts } \\
\text { and presents the } \\
\text { correct result }\end{array}$ & $\begin{array}{l}\text { Able to calculate the } \\
\text { numerator and } \\
\text { denominator correctly } \\
\text { but did not present the } \\
\text { result correctly; }\end{array}$ & $\begin{array}{l}\text { Able to calculate only } \\
\text { the numerator or } \\
\text { denominator correctly } \\
\text { but not both }\end{array}$ & $\begin{array}{l}\text { Not able to perform the } \\
\text { calculation }\end{array}$ \\
\hline $\begin{array}{l}\text { Assessment of } \\
\text { liquidity }\end{array}$ & $\begin{array}{l}\text { Defined concept of } \\
\text { liquidity, selected } \\
\text { appropriate ratio for } \\
\text { discussion, identified a } \\
\text { measurement for the } \\
\text { ratio and properly } \\
\text { interpreted ratio result } \\
\text { in drawing a } \\
\text { conclusion about the } \\
\text { liquidity position of } \\
\text { the company }\end{array}$ & $\begin{array}{l}\text { Did not define } \\
\text { concept, however, did } \\
\text { select the appropriate } \\
\text { ratio and properly } \\
\text { interpreted ratio result } \\
\text { in drawing a } \\
\text { conclusion about the } \\
\text { liquidity position of } \\
\text { the company }\end{array}$ & $\begin{array}{l}\text { Did not define concept, } \\
\text { did not select the } \\
\text { appropriate ratio to } \\
\text { support concept, but } \\
\text { did provide some } \\
\text { rationale conclusions } \\
\text { concerning the } \\
\text { liquidity of the } \\
\text { company }\end{array}$ & $\begin{array}{l}\text { Provided no support or } \\
\text { analysis, simply } \\
\text { indicate the position is } \\
\text { good or bad. }\end{array}$ \\
\hline $\begin{array}{l}\text { Assessment of } \\
\text { financial flexibility }\end{array}$ & $\begin{array}{l}\text { Defined concept of } \\
\text { financial flexibility, } \\
\text { selected appropriate } \\
\text { ratio for discussion, } \\
\text { identified a } \\
\text { measurement for the } \\
\text { ratio and properly } \\
\text { interpreted ratio result } \\
\text { in drawing a } \\
\text { conclusion about the } \\
\text { financial flexibility } \\
\text { position of the } \\
\text { company }\end{array}$ & $\begin{array}{l}\text { Did not define } \\
\text { concept, however, did } \\
\text { select the appropriate } \\
\text { ratio and properly } \\
\text { interpreted ratio result } \\
\text { in drawing a } \\
\text { conclusion about the } \\
\text { financial flexibility of } \\
\text { the company }\end{array}$ & $\begin{array}{l}\text { Did not define concept, } \\
\text { did not select the } \\
\text { appropriate ratio to } \\
\text { support concept, but } \\
\text { did provide some } \\
\text { rationale conclusions } \\
\text { concerning the } \\
\text { financial flexibility of } \\
\text { the company }\end{array}$ & $\begin{array}{l}\text { Provided no support or } \\
\text { analysis, simply } \\
\text { indicate the position is } \\
\text { good or bad. }\end{array}$ \\
\hline
\end{tabular}


Exhibit 2: The Examination Question On Cash Flows This Is The Exam Question For Fall 2005:

Name

Preparation of a Statement of Cash Flows

A comparative balance sheet for EM Corporation is presented below:

$\begin{array}{llll} & \text { 31-Dec } & \mathbf{3 1 - D e c} & \text { Change } \\ & \mathbf{2 0 0 4} & \mathbf{2 0 0 3} & \\ \text { Cash } & 63000 & 22000 & 41000 \\ \text { Accounts Receivable } & 85000 & 76000 & 9000 \\ \text { Inventories } & 180000 & 189000 & -9000 \\ \text { Land } & 75000 & 100000 & -25000 \\ \text { Equipment } & 260000 & 200000 & 60000 \\ \text { Acc. Dep -equip } & \underline{-66000} & \underline{-42000} & \underline{-24000} \\ \text { Total assets } & \underline{597000} & \underline{545000} & \underline{52000} \\ & & & \\ \text { Liabilities and Equity } & & 47000 & -13000 \\ \text { Accounts payable } & 34000 & 200000 & -50000 \\ \text { Bonds payable } & 150000 & 164000 & 50000 \\ \text { Common stock } \$ \text { 1 par) } & 214000 & \underline{134000} & \underline{65000} \\ \text { Retained earnings } & \underline{199000} & \underline{545000} & \underline{52000} \\ \text { Total Liab. \& SE } & \underline{597000} & & \end{array}$

Additional information:

1 Net income for 2004 was $\$ 125,000$

2 Cash dividends of $\$ 60,000$ were declared and paid

3 Bonds payable, which are all long-term, amounting to $\$ 50,000$ were retired using cash

4 Common stock was issued for $\$ 50,000$ cash

Required

1. Prepare a statement of cash flows for 2004

a) What was the amount of cash flows from operating activities?

b) What was the amount of cash flows from investing activities?

c) What was the amount of cash flows from financing activities?

2. Compute the following cash-basis ratios: Show the elements in the numerator and denominator as well as the calculations

a) Current cash debt coverage ratio

b) Cash debt coverage ratio

c) Current ratio

d) Acid-test (quick) ratio

3. Comment on the company's liquidity. Include at least one relevant ratio to support your conclusion.

4. Comment on the company's financial flexibility Include at least one relevant ratio to support your conclusion. 


\section{REFERENCES}

1. Ammons, Janice and Sherry Mills, (2005) Course-Embedded Assessments for Evaluating Cross-Functional Integration and Improving the Teaching-Learning Process, Issues in Accounting Education, February, Vol. 20, No. 1, pg 1-16.

2. Baril, Charles P., Billie M. Cunningham, David R. Frodham, Robert Gardner, and Susan Wolcott, (1998) Journal of Accounting Education, Summer/Fall, Vol 16, Issue 3,4; p. 381.

3. Bonk, Curtis, J. Smith, and G. Stevenson, (1998) Alternative Instructional Strategies for Creative and Critical Thinking in the Accounting Curriculum, Journal of Accounting Education, Spring, Vol 16, Issue 2, pg 261.

4. Burnett, Sharon, (2003) The Future of Accounting Education: A Regional Perspective, Journal of Education for Business, Jan/Feb. Vol 78, Issue 3 pg 129.

5. Doney, Lloyd, N. Lephardt, and James Treby, (1993) Journal of Education for Business, May, Vol 68, Issue 5, pg 297.

6. Peter Facione (2004) Critical Thinking: What it Is and Why It Is. Onsight Assessment, www.insightassessment.com, Counts: 2004 Update.

7. Friedina, John M. (1995) The Effects of Different Teaching Approaches on Students' Perceptions of the Skills Needed for Success in Accounting Courses and by Practicing Accountants Issues in Accounting Education Spring, Vol 10, Issue 1, pg 47.

8. Kealey, Holland and Watson: (2005) Preliminary Evidence on the Association between Critical Thinking and Performance in Principles of Accounting, Issues in Accounting Education Feb. Vol. 20, No.1 pg. 33-49.

9. Kimmel, Paul (2005) A Framework for Incorporating Critical Thinking into Accounting Education, Journal of Accounting Education, Summer 1995, Vol. 13, Issue 3, pg. 299.

10. Lynch, Cindy and Susan Wolcott (2001), Helping Your Students Develop Critical Thinking Skills, Idea Center, Idea Paper \#37, October 2001, found in Wolcott, S.K. and Lynch, C. I. Task Prompts for Different Levels in Steps for Better Thinking (online), http: www.WolcottLynch.com.

11. Reinstein, Alan, and Mohamed Bayou, (1997) Management Auditing Journal, Vol 12, Issue 7, Pg 336.

12. Riordan, Michael and E. Kent St. Pierre, (1992) The Development of Critical Thinking, Management Accounting, Feb., Vol 73, Issue 8, pg 63.

13. Scriven and Paul (2005) Defining Critical Thinking 8/20/2005 www.criticalthinking.org/aboutCT/definingCT.shtml.

14. Springer, Carol W. and A. Faye Borthick, (2004) Business Simulation to Stage Critical Thinking in Introductory Accounting: Rationale, Design and Implementation, Issues in Accounting Education, 2004, Vol 19, Issue 3, pg 227-304.

15. Wiggins, G. 1998 Educative Assessment: Designing Assessments to Inform and Improve Student Performance, San Francisco, Jossey-Bass.

16. Wolcott, Susan, Charles Baril, Billie Cunningham, David Fordham, and Kent St.Pierre Critical Thought on Critical Thinking Research Journal of Accounting Education 2002 v. 20 (2, Spring) 85-103.

17. Wolcott, Susan and C.L. Lynch, Critical Thinking in the Accounting Classroom: A Reflective Judgment Developmental Process Perspective, Accounting Education: A Journal of Theory, Practice and Research, 1997 Vol 2, Issue 1, pg. 59-78. 